\title{
Intracortical Microelectrode Array Unit Yield under Chronic Conditions: A Comparative Evaluation
}

\author{
Joshua O. Usoro ${ }^{1}{ }^{\complement}$, Brandon S. Sturgill ${ }^{1}$, Kate C. Musselman ${ }^{1}$, Jeffrey R. Capadona ${ }^{2,3}$ and Joseph J. Pancrazio ${ }^{1, *}$ \\ 1 Department of Bioengineering, The University of Texas at Dallas, Richardson, TX 75080, USA; \\ joshua.usoro@utdallas.edu (J.O.U.); brandon.sturgill@utdallas.edu (B.S.S.); \\ katecmusselman@gmail.com (K.C.M.) \\ 2 Department of Biomedical Engineering, Case Western Reserve University, Cleveland, OH 44106, USA; \\ jrc35@case.edu \\ 3 Advanced Platform Technology Center, L. Stokes Cleveland VA Medical Center, Rehabilitation Research and \\ Development, Cleveland, OH 44106, USA \\ * Correspondence: joseph.pancrazio@utdallas.edu
}

Citation: Usoro, J.O.; Sturgill, B.S.; Musselman, K.C.; Capadona, J.R.; Pancrazio, J.J. Intracortical Microelectrode Array Unit Yield under Chronic Conditions: A Comparative Evaluation.

Micromachines 2021, 12, 972. https://doi.org/10.3390/mi12080972

Academic Editor: Seong-O Choi

Received: 21 May 2021

Accepted: 12 August 2021

Published: 17 August 2021

Publisher's Note: MDPI stays neutral with regard to jurisdictional claims in published maps and institutional affiliations.

Copyright: (c) 2021 by the authors. Licensee MDPI, Basel, Switzerland. This article is an open access article distributed under the terms and conditions of the Creative Commons Attribution (CC BY) license (https:// creativecommons.org/licenses/by/ $4.0 /)$.

\begin{abstract}
While microelectrode arrays (MEAs) offer the promise of elucidating functional neural circuitry and serve as the basis for a cortical neuroprosthesis, the challenge of designing and demonstrating chronically reliable technology remains. Numerous studies report "chronic" data but the actual time spans and performance measures corresponding to the experimental work vary. In this study, we reviewed the experimental durations that constitute chronic studies across a range of MEA types and animal species to gain an understanding of the widespread variability in reported study duration. For rodents, which are the most commonly used animal model in chronic studies, we examined active electrode yield (AEY) for different array types as a means to contextualize the study duration variance, as well as investigate and interpret the performance of custom devices in comparison to conventional MEAs. We observed wide-spread variance within species for the chronic implantation period and an AEY that decayed linearly in rodent models that implanted commerciallyavailable devices. These observations provide a benchmark for comparing the performance of new technologies and highlight the need for consistency in chronic MEA studies. Additionally, to fully derive performance under chronic conditions, the duration of abiotic failure modes, biological processes induced by indwelling probes, and intended application of the device are key determinants.
\end{abstract}

Keywords: neural interface; microelectrode array; intracortical; chronic; active electrode yield

\section{Introduction}

Neural interfaces have garnered tremendous interest in recent years due to their ability to record from and stimulate neuronal populations. These devices have provided an increased understanding of neuronal network dynamics underlying behavior and enabled a variety of clinical applications ranging from controlling text and cursors on a screen [1-3] to restoring lost motor and sensory functionality [4-9]. Neural interfaces for the central nervous system range from completely non-invasive (e.g. electroencephalography scalp electrodes), to epi/subdural electrocorticography arrays, to invasive intracortical microelectrode arrays (MEAs). While these devices all have tradeoffs between resolution of neural activity and invasiveness, intracortical MEAs have attracted significant attention due to their ability to interface with individual neurons and neural ensembles, which when coupled with recent advancements in computational capabilities, allows for a relatively high level of specificity and volitional control [10].

Intracortical MEAs are characterized by electrodes with geometric surface areas that are typically smaller than $10,000 \mu \mathrm{m}^{2}$ [11], that record and/or stimulate from within the cortex. Historically, these MEAs have been classified into three types of devices: microwire arrays, fabricated planar arrays, and machined arrays. Microwires are comprised of a core 
conducting wire generally constructed from tungsten, stainless steel, iridium, or platinum, and an insulator that typically consists of glass, parylene-C, polyimide, or Teflon. The insulation is commonly removed/exposed at the tip to create the recording site.

Planar arrays are historically fabricated from a rigid silicon substrate using photolithographic techniques in which layers of conductive and nonconductive materials are deposited in thin films to build up a planar structure. Conductive traces and electrodes are often made from metals such as gold or iridium and are insulated using polymer coatings similar to those used in microwires.

Machined arrays use a dicing, etching, and glass reflow process to mill a block of silicon into a bed of penetrating needle-shaped shanks. Electrode material (often platinum or iridium) is then deposited on the shanks, followed by an insulator that is etched away at the tips to expose the recording sites, similar to microwires.

Regardless of the type, each of the MEAs suffers from reliability issues over long periods of implantation. While there are both biotic and abiotic factors that influence reliability [12-14], the neural interfaces field is exploring a wide range of approaches spanning novel constituent materials and coatings [15-18] to ultrasmall dimensions [19-21] to pharmacological interventions [22-24] to achieve chronic reliability. With rapid advancement in MEA technology however, the question arises as to how to best contextualize and compare both the performance of novel devices to other custom-built or conventional arrays, as well as the duration for demonstrating this performance.

In this study, we performed a comprehensive evaluation of studies published within the past 35 years that conducted experiments using intracortical MEAs where authors claimed either "chronic" or "long-term" experimentation. We then compiled and analyzed the data by correlating the corresponding timepoints within studies to a variety of metrics to gain a better understanding of the criteria involved in determining chronic performance. Furthermore, for studies involving rodents, the most widely used animal model for chronic experimentation, we evaluated the utility of using active electrode yield as a means to contextualize and compare the performance of novel and conventional MEAs. What emerges is a consensus- and biologically-based rationale for chronic study duration, as well as a performance metric guided by a decay rate that informs the evaluation of prior work and the design of future MEA studies for fundamental and preclinical research.

\section{Materials and Methods}

\subsection{Search Strategy}

A systematic search was conducted to collect a representative sample of the chronic intracortical MEA literature. The following search terms were used to identify articles in Google Scholar, PubMed, and Web of Science: chronic, long-term, intracortical implantation, microelectrode array, chronic MEA, brain interface, neural interface, and cortical electrode array. Additional manual searches were performed using the references of articles that were identified for inclusion in the study.

\subsection{Inclusion/Exclusion Criteria}

This study only included peer-reviewed articles that reported implanting a microelectrode array into the cortex of the brain for a "chronic" or "long-term" duration. A microelectrode array was defined as a having an electrode geometric surface area of less than $10,000 \mu \mathrm{m}^{2}$ [11], thereby excluding many studies involving deep brain stimulating electrodes. Studies were excluded if they reported a "semi-chronic" timepoint or if they alluded to a chronic duration but did not provide an actual number of days/weeks over which the study was conducted. Articles reporting the use of electrocorticography arrays were also excluded as these devices typically lie on surface of the brain and do not penetrate the cortex. 


\subsection{Selection and Sorting of Studies}

After the initial search, titles and abstracts were evaluated to determine relevance to the study. Articles that passed the initial assessment and appeared likely to meet the inclusion criteria were then analyzed using the full text. Emphasis was placed on preclinical studies in order to better assess trends within academic and institutional research environments. Once it was confirmed that the article met the inclusion criteria, pertinent data was extracted and sorted by animal model, device used, and year published. The "Animal Model" grouping was broadly split into 5 categories: (1) Mouse, (2) Rat, (3) Small Animal (bird (finch/budgerigar), cat (domestic), guinea pig (domestic), pig (domestic), rabbit (domestic)), (4) Non-human Primate, and (5) Human. The "Device Used" grouping was divided into 4 categories: (1) Microwire, (2) NeuroNexus (planar arrays), (3) Blackrock (machined arrays), and (4) Custom, i.e., any study that described in-house fabrication or modification of commercially-available devices. This was done to intrinsically separate the commercial devices by fabrication methods, dimensions, and applications, as these could have a large effect on chronic duration. The "Year Published" grouping was conducted in 5-year increments. The chronic time point was recorded as the researcher's intended experimental design duration. If none was explicitly stated, the time point at which the majority of data collection ended. For example, there were multiple studies in which a researcher continued to collect data somewhat indefinitely from one remaining animal to determine how long physiological signals could be detected. If multiple time points were reported (e.g., histological endpoints), the longest duration was recorded.

\subsection{Active Electrode Yield}

For studies involving the use of rodents, active electrode yield (AEY), defined as the percentage of electrodes that recorded one or more identifiable units, was extracted at the earliest and latest timepoints that the data were reported. AEY was chosen as the representative performance metric due to its consistency in reporting, and similarity in acquisition and calculation across studies, as opposed to measures such as signal-to-noise ratio, electrochemical properties, and histological outcomes, which can vary drastically between studies and devices [24-29]. As an example, consider the utility of SNR across multiple studies. Kozai et al. (2017) defined SNR as PP/ $\left(2^{*} \sigma\right)$ where PP is the average peak-to-peak amplitude of an identified single unit and $\sigma$ is the standard deviation or, equivalently, the root mean square of the noise [30]. In contrast, Mols et al. (2017) defined SNR as PP/ $\left(6^{*} \sigma\right)$ whereas others may have quantified SNR in their analyses but not offered a definition in the text (Luan et al., 2017) [31,32]. Curve fitting was conducted on AEY as a function of post-implantation duration to determine decay rates associated with potential decreases in device performance. A curve was considered "fit" if the Chi-Square tolerance was below $1 \times 10^{-9}$ and the adjusted $R^{2}$ value exceeded 0.5 .

\section{Results}

The initial search yielded approximately 300 articles, of which 158 articles (162 data points) were ultimately chosen for inclusion in this survey. A few human studies were included to provide a more complete overview of intracortical MEA use, but the vast majority of selected articles and the ensuing analysis focused on preclinical models originating in North America. To examine trends in how the term "chronic" was used, articles were grouped based on the animal model and device reported in the study, as well as the year the study was published.

The animal model group was broken down by size and prevalence in research, resulting in separate categories for mouse and rat, as well a "small animal group" for less commonly used species. For studies that reported using multiple animal models, each species was included as a distinct entry for data collection purposes, but did not affect the overall total number of articles. A breakdown of the groupings can be seen in Figure 1 and Table 1. 


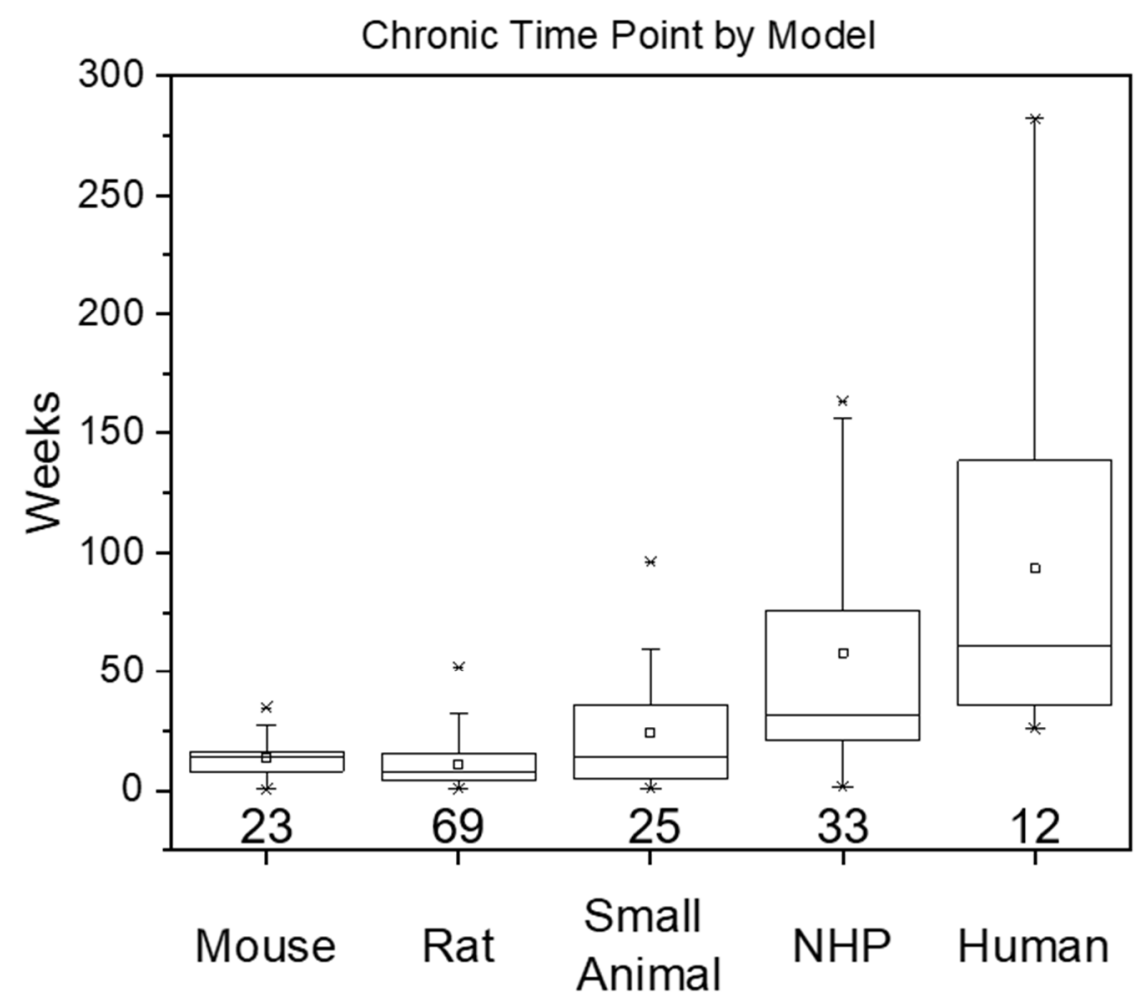

Figure 1. Chronic durations based on animal species. The box is determined by the 25th and 75th percentiles while the whiskers indicate 1.5 times the interquartile range. The minimum and maximum are represented by asterisks while the horizontal line and small square within the box indicate the median and mean, respectively. The numbers below each box and whisker plot reflect the number of studies contributing to the plot.

Table 1. Chronic time point statistics based on model.

\begin{tabular}{cccccc}
\hline Metric (in Weeks) & Mouse & Rat & Small Animal & Non-Human Primate & Human \\
\hline Number of Studies & 23 & 69 & 25 & 33 & 12 \\
Mean & 13.5 & 10.8 & 25.1 & 58.0 & 93.3 \\
Median & 12.0 & 8.00 & 14.3 & 31.9 & 61.0 \\
Range & $0.429-34.7$ & $1.00-52.0$ & $0.700-96.0$ & $1.43-163$ & $26.0-282$ \\
Standard Deviation & 8.70 & 9.40 & 23.3 & 53.0 & 77.3 \\
References & {$[24,25,31-50]$} & $29,33,38,48,26-$ & {$[111-135]$} & {$[3,133,136-164]$} & {$[1,4,7,165-173]$} \\
\hline
\end{tabular}

The rat model was the most common of the animal models with a relatively even distribution among the mouse, small animal, and non-human primate group. The mouse and rat models exhibited similar means and medians, whereas the remaining groups displayed increasing chronic durations that scaled to the expected lifespan of the animal model. The variation within each group was quite large, with standard deviations ranging from $64-96 \%$ of the mean and medians that substantially differed from the means. This widespread variation highlights the lack of established standards in the field regarding the definition or use of the term "chronic" in this experimental context. Furthermore, the mouse, rat, and small animal models all included studies that reported chronic durations that were $\leq 1$ week, while the non-human primate group included a chronic time point that was $\leq 2$ weeks, despite mounting evidence that the dynamic phase of the neuroinflammatory response due to probe implantation may last for several weeks and the neuroinflammatory response due to the MEA may continue for 8-16 weeks [12,14,65,77,174-176]. Interestingly, the increase in animal model size and complexity also mapped to an increased average life expectancy [177], suggesting that the demonstration and expectation of device longevity and performance may be influenced by animal model selection (Supplementary Figure S1). 
The use of the term chronic was also explored as a function of the type of implant used: Microwire, Neuronexus, Blackrock, or Custom. Figure 2 shows that the majority of studies used custom-made devices in their experiments, with all groups reporting high levels of variation similar to Figure 1.

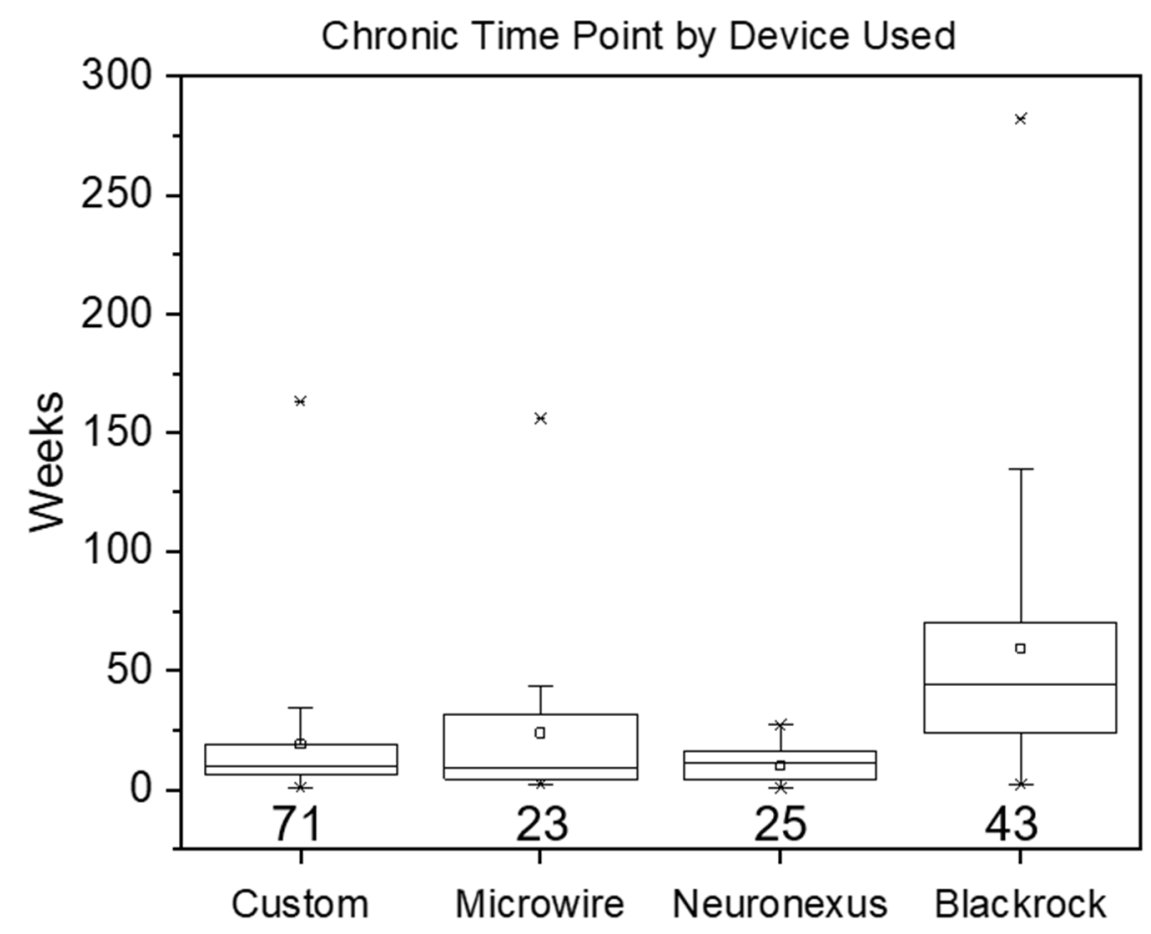

Figure 2. Chronic durations based on implanted device. The box is determined by the 25th and 75 th percentiles while the whiskers indicate 1.5 times the interquartile range. The minimum and maximum are represented by asterisks while the horizontal line and small square within the box indicate the median and mean respectively. The numbers below each box and whisker plot reflect the number of studies contributing to the plot.

It is worth noting that the means of each device group appear to correlate with different animal models. The Neuronexus, Microwire, and Blackrock averages reflect the rat, small animal, and non-human primate/human models, respectively. This is not surprising for the latter, given that most of the work performed in non-human primates and humans utilize the Blackrock array. When examining the medians however, the same trend is not observed (Supplemntary Table S1). The Custom, Microwire, and Neuronexus groups all reflect medians similar to that of the rat/mouse model. Additionally, the median of the Custom device group falls on the shorter end of the spectrum, on par with Microwires which were traditionally used in acute experiments. This may be because custom devices are typically examined in a mouse/rat model which provides a low cost and well-studied means of testing novel arrays. To this end, we also asked how the device used may influence the definition of a chronic duration in the mouse and rat model (Supplementary Tables S2 and S3). Supplmentary Tables S2 and S3 confirm that custom arrays were in fact the most widely used devices in the mouse and rat models. In the rat model, the means and medians were comparable across Custom, Microwire, and Neuronexus arrays, indicating that custom devices were not held to a different standard of chronic duration when compared to some commercially-available devices. Blackrock devices in rats did exhibit a longer duration, however. Additionally, there were no substantial differences observed in the mean or median chronic duration when comparing the devices used in the mouse model.

Extending this analysis to the other animal models, a longer duration was observed for small animal studies utilizing the Blackrock array as compared to the other array types (Supplementary Table S4). The mean chronic duration for non-human primate studies were 
consistent, but the median did increase from Custom, to Microwire, to Blackrock arrays, and for the human model there is insufficent data due to the blackrock array being almost exclusievely used (Supplementary Tables S5 and S6). As seen in Supplementary Table S7 no trends were observed for chronic duration as a function of the study publication year; furthermore, Supplementary Tables S8-S12 have data for chronic duration by publication year for each animal model.

Additionally, It is possible that the country where the research was conducted may influence durations of studies based on local social, ethical or legal considerations. We investigated whether there were differences between chronic time points in different geographical regions (Supplementary Tables S13-S16). We found that there was still widespread variability within each of the geographical regions we reviewed (North America (0.4-282 weeks), Europe (0.7-30 weeks), Asia (4-98.6 weeks), Other (1-36 weeks)) with comparable medians and/or means. The overwhelming majority of studies constituting this review originated from North America (132/158) indicating that the trends observed are unlikely to be influenced by country of origin.

In an effort to gain insight into array performance across device types and studies over reported chronic duration, we extracted information related to recording performance, i.e., the ability of the array to measure physiologically relevant signals. AEY is generally reported as a percentage of electrodes that recorded one or more identifiable units and is valuable as a recording metric because of its consistency between animal models (underlying electrophysiology remains the same) and studies (calculated as a simple percentage), as opposed to the numerous formulas used to calculate signal-to-noise ratio, as well as electrochemical measurements that vary widely based on electrode dimension, roughness, and material composition. Because AEY is not as widely reported in larger animal experiments, and due to the high number of, and average duration similarities between, mouse and rat studies, our analysis focused on a combined rodent model.

Figure 3A shows reported AEY measurements across different device types. Microwire, Neuronexus, and Blackrock arrays all exhibited a general decline in AEY over time, with yields at or below $30 \%$ after 16 weeks post-implantation. Custom arrays, however, did not exhibit any discernible trend over time, with studies reporting AEY between 15-75\% at Week 16, highlighting the widespread variance in the performance of custom arrays. The distribution of Custom AEY appeared almost bimodal, with most yields falling between either $15-25 \%$ or $65-75 \%$.

We recognize that novel devices comprising the "custom" group may not have fully mature fabrication processes. As a result, custom devices may have a lower fabrication yield characterized by fewer functional microelectrode sites or entire devices that were non-functional. Often, impedance measurements were used to qualify devices at an individual channel basis [30,92]. For example, Luan et al. (2017) reported a fabrication yield for connected microelectrode channels of $83 \%$ for the ultraflexible intracortical probes. Likewise, Guan et al. (2019) reported that processing steps to produce neurotassel technology resulted in a device yield of $>80 \%$. In each case, studies excluded non-functional microelectrode sites and, in some cases, entire devices when evidence indicated that the custom probes exhibited physical defects [32,46].

The stark difference in performance at similar timepoints is likely, in part, due to the various fabrication techniques and material composition used across studies, emphasizing the need for methodology to aid in the direct comparison of novel arrays. To this end, we investigated the use of curve fitting as a means to calculate the decay rate of AEY. Because our goal was to evaluate a standardization method for comparison of novel devices, we focused our curve fitting analysis on Neuronexus and Blackrock arrays $(n=24)$, the current standards for commercially-available MEA technology, and the most widely used and directly comparable devices across studies. Several fitting models were tested on the commercially-available AEY distribution including single and two-phase exponential decays, with the linear model providing the best fit. The linear model resulted in an adjusted $R^{2}$ value of 0.67 and a Pearson's $R$ of -0.83 , indicating a strongly negative 
correlation between AEY and time (as expected) with a model fit that far exceeded chance (Figure 3B). The linear fit produced an initial AEY value of approximately $75 \%$ and slope of -2.2 percent/week, suggesting that these commercially-available devices can be expected to exhibit a relatively high level of performance early on in a study, but may experience a decline of approximately $50 \%$ in performance over the course of 16 weeks.

A

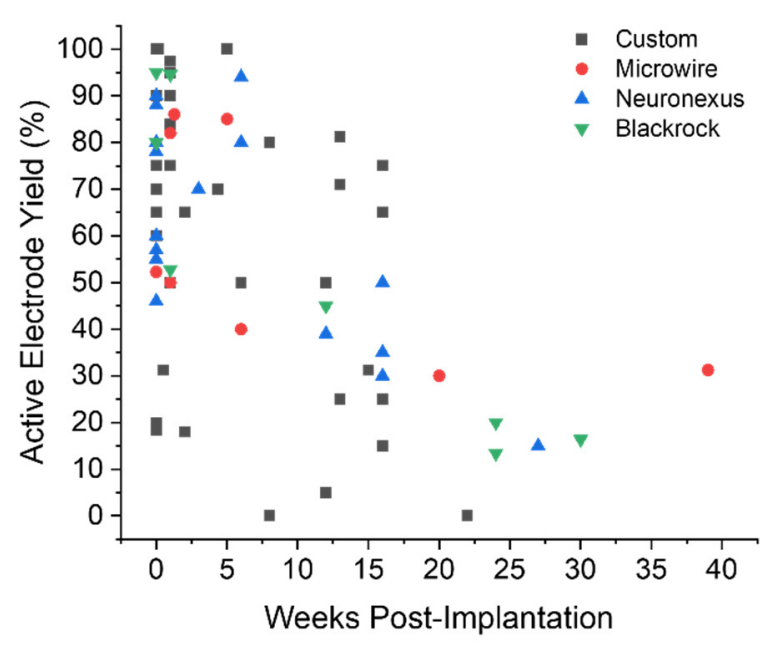

B

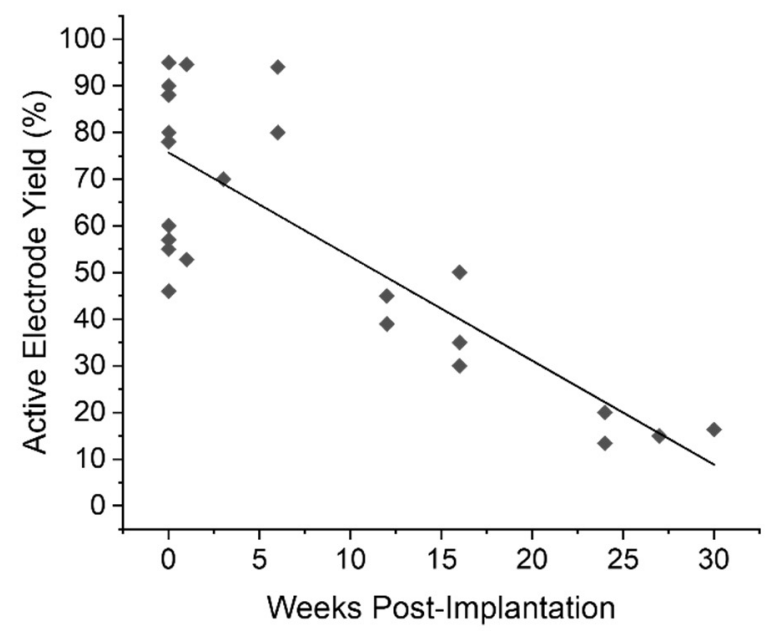

Figure 3. Active electrode yield over time. (A) A scatterplot of initial and final active electrode yield percentages for Custom (black square), Microwire (red circle), Neuronexus (blue triangle), and Blackrock (green inverted triangle) as reported by the original studies. (B) Curve fitting of a scatterplot consisting of commercially-fabricated devices (Neuronexus and Blackrock). The curve resulted in an initial AEY value of $\sim 75 \%$ and slope of -2.2 percent/week with adjusted $\mathrm{R}^{2}$ and Pearson's $\mathrm{R}$ values of 0.67 and -0.83 respectively. Data used to create Figure 3 was extrapolated from the references as follows: Custom [16,30,32,51,52,55,61,62,71,84,88,92], Microwire [58,63,81,82], Neuronexus [24-27,44,68,91], Blackrock [29,98,99,103].

\section{Discussion}

In this study, we report how researchers define the term "chronic" in intracortical microelectrode array applications. To our knowledge, this is the first systematic review on the use and interpretation of chronic duration in this field to date. By analyzing literature across various animal models and devices, this study highlights how variable the use of "chronic" or "long-term" is. For example, we see studies from North America tend to have longer time points than the rest of the globe (Table S14). This may be due to differences in regulations affecting study duration or animal models used in each region. Although the mean time point for North America may be skewed to longer durations by a few studies, the median is similar to the European studies used in this review. Together this accounts for most of the studies observed. Additionally, the median time point appears to be converging over the last decade. However, there is a large range of timepoints noted as chronic across studies. It is noteworthy that the majority of the studies, but not all, have durations that are at least 8 weeks in duration consistent with a biologically relevant timepoint. This reaffirms the need for a common interpretation so comparisons between studies for evaluating the long-term performance of this technology are possible. Moreover, our evaluation of the decay rate of AEY, an electrophysiological performance measure common to many MEA studies, may be useful in helping to contextualize the long-term performance of novel arrays by serving as a generalizable standard of comparison.

\subsection{Intended Application and Abiotic Considerations}

The primary function of intracortical MEAs is to serve as a gateway into the nervous system, interfacing with the body to enhance our understanding of the underlying physiology and enable applications in motor and sensory functional improvements. In chronic 
experimentation, it is therefore of paramount importance to first characterize the long-term use of these devices based on their intended application and the ability of the device to perform as expected throughout the duration of anticipated use. Given the ever-increasing number of ways in which this technology could be utilized, intended application in this context can be broadly generalized and divided into two categories: basic science and task performance. For studies aiming to answer questions regarding the fundamental science underlying physiology (e.g., foreign body response, plasticity, molecular pathways, etc.), the chronic duration of the experiment will largely be determined by the time course of the physiologic occurrence in question. Furthermore, these types of studies are typically carried out in a rodent model due to its low cost and well-studied nature, so chronic duration may also be influenced by the animal model selection as well. For studies that aim to evaluate the use of MEAs to aid in performing specific tasks however (e.g., control of neuroprostheses, moving a computer cursor, or functional electrical stimulation), one could argue that the rehabilitative nature of these applications necessitate chronic durations that ideally last the lifetime of the patient. Given the current limitations of this technology though [12-14,178], it is unrealistic to expect MEAs to maintain functionality for this long. What may be a more useful approach in determining chronic durations is to partially base them on the limitations themselves. MEA failure modes can be categorized as either biotic, abiotic, or a combination of both. This study does not go into detail about abiotic failure modes (see $[13,39,82,179]$ ), but given the myriad materials, geometries, fabrication methods, and surgical techniques involved in implementing MEAs, it becomes increasingly difficult to pinpoint a chronic duration based on this metric alone, signifying that a range of durations may be necessary to account for the vast differences between devices.

For research in which the primary purpose is to demonstrate long-term device functionality (electrophysiological or electrochemical), it may be prudent to include a performance metric component alongside the experimental duration rationale. Similar to the AEY decay rate evaluated in this study (Figure 3), using comparable device- or animal-specific decay curves may provide a means by which to interpret the success of new technology, irrespective of material composition, geometries, or fabrication methods. Furthermore, utilizing these performance-based metrics in combination with experimental duration rationale may also aid in the interpretation of the performance of novel technology when compared to commercially-available devices.

\subsection{Biological Considerations}

The biological neuroinflammatory response to the implanted device is believed to be a major source of intracortical microelectrode failure, and should be considered, in part, in the definition of the time course of deployment within a living system. The biological response to intracortical microelectrodes is well-characterized, but many of the relationships between device performance and the dynamic and changing environment adjacent to the implanted microelectrodes remains unknown. In brief, it is well-known that there are at least two phases of the foreign body response, acute and chronic. The acute phase of inflammation is defined by the exudation of fluids and plasma proteins, as well as the migration of leukocytes to the site of injury [180]. In general, acute inflammation typically only lasts from minutes to days in response to most medical device implantation. However, with respect to intracortical microelectrodes, the blood-brain barrier adds a unique dynamic. Several researchers have demonstrated that the blood-brain barrier remains leaky to both serum proteins and leukocytes as long as the intracortical microelectrodes remain implanted, suggesting that acute inflammation never completely subsides [85,181-183], despite the onset of a chronic inflammatory response and glial scar formation [184]. Due to the dual existence of both acute and chronic inflammatory states around the intracortical microelectrodes, and the regular micromotion of the microelectrode relative to the adjacent tissue [185-187], there is a continued foreign body response that persists through the indwelling period, although relatively static and consistent in their processes [188], meaning there is no sudden dynamic or drastic shift in their behavior barring any externally-triggered stimulus. The 
point at which the biological response reaches what is essentially a steady-state, should therefore be the minimum time point at which the evaluation of a device is considered chronic. Numerous articles reporting analysis in a rodent model found strong evidence that reduced blood-brain barrier integrity and neuroinflammation that were acutely caused by vascular disruption, transitioned to a sub-chronic phase at 6 weeks that was characterized by endogenous tissue events $[77,85,188-190]$. Furthermore, these studies suggested that this response reaches a steady state at $12-16$ weeks post implantation but varies largely based on the design and materials composition of the individual microelectrode [191].

\section{Conclusions}

Based on the literature survey, there is a large variation in the duration of studies that investigate the chronic performance of implanted MEAs. A focused evaluation of rodent studies that utilized commercially-available devices revealed that there is a consistent decay rate in AEY that may serve as a benchmark for comparing emerging technology. It is important to recognize that AEY does not capture the consistency of individual units over time. For this reason, AEY is necessary but perhaps insufficient to predict reliability for brain computer interface implementations that require unit consistency. Expanding on prior work that suggests that a minimum 12-16 week indwelling period may be sufficient for the assessment of chronic performance, the addition of a suitable performance metric such as AEY decay rate might aid in the contextualization and interpretation of the long-term functionality of this technology.

Supplementary Materials: The following are available online at https:/ /www.mdpi.com/article/10 .3390/mi12080972/s1, Figure S1: Chronic durations based on life expectancy, Table S1: Chronic time point statistics based on device used, Table S2: Chronic time point statistics based on device used in a mouse model, Table S3: Chronic time point statistics based on device used in a rat model, Table S4: Chronic time point statistics based on device used in a small animal model, Table S5: Chronic time point statistics based on device used in a non-human primate model, Table S6: Chronic time point statistics based on device used in a human model, Table S7: Chronic time point statistics based on publication year, Table S8: Chronic time point statistics based on publication year in a mouse model, Table S9: Chronic time point statistics based on publication year in a rat model, Table S10: Chronic time point statistics based on publication year in a small animal model Table S11: Chronic time point statistics based on publication year in a non-human primate model, Table S12: Chronic time point statistics based on publication year in a human model, Table S13: Chronic time point statistics based on geographical region, Table S14: Chronic time point statistics based on animal model in North America, Table S15: Chronic time point statistics based on animal model in Europe, Table S16: Chronic time point statistics based on animal model in Asia.

Author Contributions: Conceptualization, J.O.U. and J.J.P.; methodology, J.O.U. and J.J.P.; software, J.O.U.; validation, J.O.U., B.S.S. and K.C.M.; formal analysis, J.O.U. and B.S.S.; investigation, J.O.U., J.R.C. and J.J.P.; resources, J.J.P.; data curation, J.O.U., B.S.S., K.C.M.; writing-original draft preparation, J.O.U., J.R.C., J.J.P.; writing—review and editing, J.O.U., B.S.S., K.C.M., J.R.C. and J.J.P.; visualization, J.O.U.; supervision, J.J.P.; project administration, J.O.U. and J.J.P.; funding acquisition, J.R.C. and J.J.P. All authors have read and agreed to the published version of the manuscript.

Funding: This research was funded by the National Institutes of Health R01 NS110823, R01 NS104344, and Research Career Scientist Award \# GRANT12635707 from the United States (US) Department of Veterans Affairs Rehabilitation Research and Development Service.

Institutional Review Board Statement: Not applicable.

Informed Consent Statement: Not applicable.

Data Availability Statement: Not applicable.

Conflicts of Interest: The authors declare no conflict of interest. 


\section{References}

1. Kim, S.P.; Simeral, J.D.; Hochberg, L.R.; Donoghue, J.P.; Black, M.J. Neural control of computer cursor velocity by decoding motor cortical spiking activity in humans with tetraplegia. J. Neural Eng. 2008, 5, 455-476. [CrossRef]

2. Wolpaw, J.R.; Birbaumer, N.; Mcfarland, D.J.; Pfurtscheller, G.; Vaughan, T.M. Brain—Computer interfaces for communication and control. Clin. Neurophysiol. 2002, 113, 767-791. [CrossRef]

3. Wang, D.; Zhang, Q.; Li, Y.; Wang, Y.; Zhu, J.; Zhang, S.; Zheng, X. Corrigendum: Long-term decoding stability of local field potentials from silicon arrays in primate motor cortex during a 2D center out task. J. Neural Eng. 2014, 11, 036009. [CrossRef]

4. Bouton, C.E.; Shaikhouni, A.; Annetta, N.V.; Bockbrader, M.A.; Friedenberg, D.A.; Nielson, D.M.; Sharma, G.; Sederberg, P.B.; Glenn, B.C.; Mysiw, W.J.; et al. Restoring cortical control of functional movement in a human with quadriplegia. Nature 2016, 533, 247-250. [CrossRef]

5. Collinger, J.L.; Wodlinger, B.; Downey, J.E.; Wang, W.; Tyler-Kabara, E.C.; Weber, D.J.; McMorland, A.J.C.; Velliste, M.; Boninger, M.L.; Schwartz, A.B. High-performance neuroprosthetic control by an individual with tetraplegia. Lancet 2013, 381, 557-564. [CrossRef]

6. Ganzer, P.D.; Colachis, S.C.; Schwemmer, M.A.; Weber, D.J.; Bockbrader, M.A.; Ganzer, P.D.; Colachis, S.C.; Schwemmer, M.A.; Friedenberg, D.A.; Dunlap, C.F. Restoring the Sense of Touch Using a Sensorimotor Demultiplexing Neural Interface. Cell 2020, 181, 763-773.e12. [CrossRef]

7. Hochberg, L.R.; Bacher, D.; Jarosiewicz, B.; Masse, N.Y.; Simeral, J.D.; Vogel, J.; Haddadin, S.; Liu, J.; Cash, S.S.; Van Der Smagt, P.; et al. Reach and grasp by people with tetraplegia using a neurally controlled robotic arm. Nature 2012, 485, 372-375. [CrossRef]

8. Donoghue, J.P.; Nurmikko, A.; Black, M.; Hochberg, L.R. Assistive technology and robotic control using motor cortex ensemblebased neural interface systems in humans with tetraplegia. J. Physiol. 2007, 579, 603-611. [CrossRef] [PubMed]

9. Dobelle, W.H.; Mladejovsky, M.G.; Girvin, J.P. Artificial Vision for the Blind: Electrical Stimulation of Visual Cortex Offers Hope for a Functional Prosthesis. Science 1974, 183, 440-444. [CrossRef]

10. Vargas-Irwin, C.E.; Feldman, J.M.; King, B.; Simeral, J.D.; Sorice, B.L.; Oakley, E.M.; Cash, S.S.; Eskandar, E.N.; Friehs, G.M.; Hochberg, L.R.; et al. Watch, imagine, attempt: Motor cortex single-unit activity reveals context-dependent movement encoding in humans with tetraplegia. Front. Hum. Neurosci. 2018, 12, 450. [CrossRef]

11. Cogan, S.F. Neural Stimulation and Recording Electrodes. Annu. Rev. Biomed. Eng. 2008, 10, 275-309. [CrossRef] [PubMed]

12. Polikov, V.S.; Tresco, P.A.; Reichert, W.M. Response of brain tissue to chronically implanted neural electrodes. J. Neurosci. Methods 2005, 148, 1-18. [CrossRef]

13. Barrese, J.C.; Rao, N.; Paroo, K.; Triebwasser, C.; Vargas-Irwin, C.; Franquemont, L.; Donoghue, J.P. Failure mode analysis of silicon-based intracortical microelectrode arrays in non-human primates. J. Neural Eng. 2013, 10, 066014. [CrossRef]

14. Jorfi, M.; Skousen, J.L.; Weder, C.; Capadona, J.R. Progress towards biocompatible intracortical microelectrodes for neural interfacing applications. J. Neural Eng. 2015, 12, 011001. [CrossRef]

15. Simon, D.M.; Charkhkar, H.; St. John, C.; Rajendran, S.; Kang, T.; Reit, R.; Arreaga-Salas, D.; McHail, D.G.; Knaack, G.L.; Sloan, A.; et al. Design and demonstration of an intracortical probe technology with tunable modulus. J. Biomed. Mater. Res.-Part A 2017, 105, 159-168. [CrossRef]

16. Stiller, A.M.; Usoro, J.; Frewin, C.L.; Danda, V.R.; Ecker, M.; Joshi-Imre, A.; Musselman, K.C.; Voit, W.; Modi, R.; Pancrazio, J.J.; et al. Chronic Intracortical Recording and Electrochemical Stability of Thiol-ene/Acrylate Shape Memory Polymer Electrode Arrays. Micromachines 2018, 9, 500. [CrossRef]

17. Rihani, R.T.; Stiller, A.M.; Usoro, J.O.; Lawson, J.; Kim, H.; Black, B.J.; Danda, V.R.; Maeng, J.; Varner, V.D.; Ware, T.H.; et al. Deployable, liquid crystal elastomer-based intracortical probes. Acta Biomater. 2020, 111, 54-64. [CrossRef]

18. Shen, W.; Das, S.; Vitale, F.; Richardson, A.; Ananthakrishnan, A.; Struzyna, L.A.; Brown, D.P.; Song, N.; Ramkumar, M.; Lucas, T.; et al. Microfabricated intracortical extracellular matrix-microelectrodes for improving neural interfaces. Microsystems Nanoeng. 2018, 4, 30. [CrossRef]

19. Pancrazio, J.J.; Deku, F.; Ghazavi, A.; Stiller, A.M.; Rihani, R.; Frewin, C.L.; Varner, V.D.; Gardner, T.J.; Cogan, S.F. Thinking Small: Progress on Microscale Neurostimulation Technology. Neuromodulation Technol. Neural Interface 2017, 2017, 745-752. [CrossRef]

20. Kozai, T.D.Y.; Langhals, N.B.; Patel, P.R.; Deng, X.; Zhang, H.; Smith, K.L.; Lahann, J.; Kotov, N.A.; Daryl, R. Ultrasmall implantable composite microelectrodes with bioactive surfaces for chronic neural interfaces. Nat. Mater. 2013, 11, 1065-1073. [CrossRef]

21. Deku, F.; Cohen, Y.; Joshi-Imre, A.; Kanneganti, A.; Gardner, T.J.; Cogan, S.F. Amorphous silicon carbide ultramicroelectrode arrays for neural stimulation and recording. J. Neural Eng. 2018, 15, 016007. [CrossRef]

22. Potter, K.A.; Buck, A.C.; Self, W.K.; Callanan, M.E.; Sunil, S.; Capadona, J.R. The effect of resveratrol on neurodegeneration and blood brain barrier stability surrounding intracortical microelectrodes. Biomaterials 2013, 34, 7001-7015. [CrossRef] [PubMed]

23. Zhong, Y.; Bellamkonda, R.V. Dexamethasone Coated Neural Probes Elicit Attenuated Inflammatory Response and Neuronal Loss Compared to Uncoated Neural Probes. Brain Res. 2007, 23, 15-27. [CrossRef]

24. Golabchi, A.; Wu, B.; Li, X.; Carlisle, D.L.; Kozai, T.D.Y.; Friedlander, R.M.; Cui, X.T. Melatonin improves quality and longevity of chronic neural recording. Biomaterials 2018, 180, 225-239. [CrossRef] [PubMed] 
25. Kozai, T.D.Y.; Du, Z.; Gugel, Z.V.; Smith, M.A.; Chase, S.M.; Bodily, L.M.; Caparosa, E.M.; Friedlander, R.M.; Cui, X.T. Comprehensive chronic laminar single-unit, multi-unit, and local field potential recording performance with planar single shank electrode arrays. J. Neurosci. Methods 2015, 242, 15-40. [CrossRef] [PubMed]

26. Vetter, R.J.; Williams, J.C.; Hetke, J.F.; Nunamaker, E.A.; Kipke, D.R. Chronic neural recording using silicon-substrate microelectrode arrays implanted in cerebral cortex. IEEE Trans. Biomed. Eng. 2004, 51, 896-904. [CrossRef] [PubMed]

27. Ludwig, K.A.; Miriani, R.M.; Langhals, N.B.; Joseph, M.D.; Anderson, D.J.; Kipke, D.R. Using a common average reference to improve cortical neuron recordings from microelectrode arrays. J. Neurophysiol. 2009, 101, 1679-1689. [CrossRef]

28. Gabran, S.R.I.; Salam, M.T.; Dian, J.; El-hayek, Y.; Velazquez, J.L.P.; Genov, R.; Member, S.; Carlen, P.L.; Salama, M.M.A.; Mansour, R.R. 3-D Flexible Nano-Textured High-Density Microelectrode Arrays for High-Performance. IEEE Trans. Neural Syst. Rehabil. Eng. 2014, 22, 1072-1082. [CrossRef] [PubMed]

29. Usoro, J.O.; Shih, E.; Black, B.J.; Rihani, R.T.; Abbott, J.; Chakraborty, B.; Pancrazio, J.J.; Cogan, S.F. Chronic stability of local field potentials from standard and modified Blackrock microelectrode arrays implanted in the rat motor cortex. Biomed. Phys. Eng. Express 2019, 5, 065017. [CrossRef]

30. Kozai, T.D.Y.; Catt, K.; Du, Z.; Na, K.; Srivannavit, O.; Haque, R.U.M.; Seymour, J.; Wise, K.D.; Yoon, E.; Cui, X.T. Chronic In Vivo evaluation of PEDOT/CNT for stable neural recordings. IEEE Trans. Biomed. Eng. 2016, 63, 111-119. [CrossRef]

31. Mols, K.; Musa, S.; Nuttin, B.; Lagae, L.; Bonin, V. In vivo characterization of the electrophysiological and astrocytic responses to a silicon neuroprobe implanted in the mouse neocortex. Sci. Rep. 2017, 7, 15642. [CrossRef] [PubMed]

32. Luan, L.; Wei, X.; Zhao, Z.; Siegel, J.J.; Potnis, O.; Tuppen, C.A.; Lin, S.; Kazmi, S.; Fowler, R.A.; Holloway, S.; et al. Ultraflexible nanoelectronic probes form reliable, glial scar-free neural integration. Sci. Adv. 2017, 3, e1601966. [CrossRef]

33. Sridharan, A.; Rajan, S.D.; Muthuswamy, J. Long-term changes in the material properties of brain tissue at the implant-tissue interface. J. Neural Eng. 2013, 10, 066001. [CrossRef]

34. Hascup, K.N.; Hascup, E.R.; Pomerleau, F.; Huettl, P.; Gerhardt, G.A. Second-by-Second Measure of L-Glutamate in the Prefontal Cortex and Striatum of Freely Moving Mice. J. Pharmacol. Exp. Ther. 2008, 2, 725-731. [CrossRef]

35. Dzirasa, K.; Fuentes, R.; Kumar, S.; Potes, J.M.; Nicolelis, M.A.L. Chronic in vivo multi-circuit neurophysiological recordings in mice. J. Neurosci. Methods 2011, 195, 36-46. [CrossRef]

36. Sawyer, A.J.; Kyriakides, T.R. Nanoparticle-based evaluation of blood-brain barrier leakage during the foreign body response. J. Neural Eng. 2013, 10, 016013. [CrossRef]

37. Hammer, D.X.; Lozzi, A.; Abliz, E.; Greenbaum, N.; Turner, K.P.; Pfefer, T.J.; Agrawal, A.; Krauthamer, V.; Welle, C.G. Optical coherence microscopy of mouse cortical vasculature surrounding implanted electrodes. Opt. Tech. Neurosurg. Neurophotonics Optogenetics 2014, 8928, 892804. [CrossRef]

38. Potter-Baker, K.A.; Ravikumar, M.; Burke, A.A.; Meador, W.D.; Householder, K.T.; Buck, A.C.; Sunil, S.; Stewart, W.G.; Anna, J.P.; Tomaszewski, W.H.; et al. A comparison of neuroinflammation to implanted microelectrodes in rat and mouse models. Biomaterials 2014, 35, 5637-5646. [CrossRef] [PubMed]

39. Kozai, T.D.Y.; Catt, K.; Li, X.; Gugel, Z.V.; Olafsson, V.T.; Vazquez, A.L.; Cui, X.T. Mechanical failure modes of chronically implanted planar silicon-based neural probes for laminar recording. Biomaterials 2015, 37, 25-39. [CrossRef]

40. Fu, T.M.; Hong, G.; Zhou, T.; Schuhmann, T.G.; Viveros, R.D.; Lieber, C.M. Stable long-term chronic brain mapping at the single-neuron level. Nat. Methods 2016, 13, 875-882. [CrossRef] [PubMed]

41. Kozai, T.D.Y.; Eles, J.R.; Vazquez, A.L.; Cui, X.T. Two-photon imaging of chronically implanted neural electrodes: Sealing methods and new insights. J. Neurosci. Methods 2016, 258, 46-55. [CrossRef] [PubMed]

42. Wei, X.; Luan, L.; Zhao, Z.; Li, X.; Zhu, H.; Potnis, O.; Xie, C. Nanofabricated Ultraflexible Electrode Arrays for High-Density Intracortical Recording. Adv. Sci. 2018, 5, 1700625. [CrossRef] [PubMed]

43. Wellman, S.M.; Kozai, T.D.Y. In vivo spatiotemporal dynamics of NG2 glia activity caused by neural electrode implantation. Biomaterials 2018, 164, 121-133. [CrossRef]

44. Golabchi, A.; Woeppel, K.M.; Li, X.; Lagenaur, C.F.; Cui, X.T. Neuroadhesive protein coating improves the chronic performance of neuroelectronics in mouse brain. Biosens. Bioelectron. 2020, 155, 112096. [CrossRef]

45. Guo, Y.; Jiang, S.; Grena, B.J.B.; Kimbrough, I.F.; Thompson, E.G.; Fink, Y.; Sontheimer, H.; Yoshinobu, T.; Jia, X. Polymer Composite with Carbon Nanofibers Aligned during Thermal Drawing as a Microelectrode for Chronic Neural Interfaces. ACS Nano 2017, 11, 6574-6585. [CrossRef]

46. Guan, S.; Wang, J.; Gu, X.; Zhao, Y.; Hou, R.; Fan, H.; Zou, L.; Gao, L.; Du, M.; Li, C.; et al. Elastocapillary self-assembled neurotassels for stable neural activity recordings. Sci. Adv. 2019, 5, eaav2842. [CrossRef]

47. Gao, L.; Wang, J.; Guan, S.; Du, M.; Wu, K.; Xu, K.; Zou, L.; Tian, H.; Fang, Y. Magnetic Actuation of Flexible Microelectrode Arrays for Neural Activity Recordings. Nano Lett. 2019, 19, 8032-8039. [CrossRef]

48. Haiss, F.; Butovas, S.; Schwarz, C. A miniaturized chronic microelectrode drive for awake behaving head restrained mice and rats. J. Neurosci. Methods 2010, 187, 67-72. [CrossRef]

49. Lecomte, A.; Degache, A.; Descamps, E.; Dahan, L.; Bergaud, C. Biostability Assessment of Flexible Parylene C-based Implantable Sensor in Wireless Chronic Neural Recording. Procedia Eng. 2016, 168, 189-192. [CrossRef]

50. Okun, M.; Lak, A.; Carandini, M.; Harris, K.D. Long term recordings with immobile silicon probes in the mouse cortex. PLoS ONE 2016, 11, e0151180. [CrossRef] [PubMed] 
51. Chen, Y.Y.; Lai, H.Y.; Lin, S.H.; Cho, C.W.; Chao, W.H.; Liao, C.H.; Tsang, S.; Chen, Y.F.; Lin, S.Y. Design and fabrication of a polyimide-based microelectrode array: Application in neural recording and repeatable electrolytic lesion in rat brain. J. Neurosci. Methods 2009, 182, 6-16. [CrossRef] [PubMed]

52. Lee, Y.; Kong, C.; Chang, J.W.; Jun, S.B. Carbon-fiber based microelectrode array embedded with a biodegradable silk support for in vivo neural recording. J. Korean Med. Sci. 2019, 34, e24. [CrossRef] [PubMed]

53. Mercanzini, A.; Colin, P.; Bensadoun, J.C.; Bertsch, A.; Renaud, P. In vivo electrical impedance spectroscopy of tissue reaction to microelectrode arrays. IEEE Trans. Biomed. Eng. 2009, 56, 1909-1918. [CrossRef] [PubMed]

54. Lind, G.; Linsmeier, C.E.; Schouenborg, J. The density difference between tissue and neural probes is a key factor for glial scarring. Sci. Rep. 2013, 3, 2942. [CrossRef]

55. Márton, G.; Orbán, G.; Kiss, M.; Fiáth, R.; Pongrácz, A.; Ulbert, I. A multimodal, SU-8-Platinum-Polyimide microelectrode array for chronic in vivo neurophysiology. PLoS ONE 2015, 10, e0145307. [CrossRef] [PubMed]

56. Rigosa, J.; Panarese, A.; Dominici, N.; Friedli, L.; Van Den Brand, R.; Carpaneto, J.; Digiovanna, J.; Courtine, G.; Micera, S. Decoding bipedal locomotion from the rat sensorimotor cortex. J. Neural Eng. 2015, 12, 056014. [CrossRef] [PubMed]

57. Ceyssens, F.; Bovet Carmona, M.; Kil, D.; Deprez, M.; Tooten, E.; Nuttin, B.; Takeoka, A.; Balschun, D.; Kraft, M.; Puers, R. Chronic neural recording with probes of subcellular cross-section using $0.06 \mathrm{~mm}^{2}$ dissolving microneedles as insertion device. Sens. Actuators B Chem. 2019, 284, 369-376. [CrossRef]

58. Nicolelis, M.A.L.; Ghazanfar, A.A.; Faggin, B.M.; Votaw, S.; Oliveira, L.M.O. Reconstructing the engram: Simultaneous, multisite, many single neuron recordings. Neuron 1997, 18, 529-537. [CrossRef]

59. Hetke, J.F.; Williams, J.C.; Pellinen, D.S.; Vetter, R.J.; Kipke, D.R. 3-D silicon probe array with hybrid polymer interconnect for chronic cortical recording. In Proceedings of the First International IEEE EMBS Conference on Neural Engineering, Capri, Italy, 20-22 March 2003; pp. 181-184. [CrossRef]

60. Szarowski, D.H.; Andersen, M.D.; Retterer, S.; Spence, A.J.; Isaacson, M.; Craighead, H.G.; Turner, J.N.; Shain, W. Brain responses to micro-machined silicon devices. Brain Res. 2003, 983, 23-35. [CrossRef]

61. Moxon, K.A.; Leiser, S.C.; Gerhardt, G.A.; Barbee, K.A.; Chapin, J.K. Ceramic-Based Multisite Electrode Arrays for Chronic Single-Neuron Recording. IEEE Trans. Biomed. Eng. 2004, 51, 647-656. [CrossRef]

62. Moxon, K.A.; Kalkhoran, N.M.; Markert, M.; Sambito, M.A.; McKenzie, J.L.; Webster, J.T. Nanostructured surface modification of ceramic-based microelectrodes to enhance biocompatibility for a direct brain-machine interface. IEEE Trans. Biomed. Eng. 2004, 51, 881-889. [CrossRef] [PubMed]

63. Rennaker, R.L.; Ruyle, A.M.; Street, S.E.; Sloan, A.M. An economical multi-channel cortical electrode array for extended periods of recording during behavior. J. Neurosci. Methods 2005, 142, 97-105. [CrossRef] [PubMed]

64. Holecko, M.M.; Williams, J.C.; Massia, S.P. Visualization of the intact interface between neural tissue and implanted microelectrode arrays. J. Neural Eng. 2005, 2, 97-102. [CrossRef]

65. Biran, R.; Martin, D.C.; Tresco, P.A. Neuronal cell loss accompanies the brain tissue response to chronically implanted silicon microelectrode arrays. Exp. Neurol. 2005, 195, 115-126. [CrossRef]

66. Cheung, K.C.; Renaud, P.; Tanila, H.; Djupsund, K. Flexible polyimide microelectrode array for in vivo recordings and current source density analysis. Biosens. Bioelectron. 2007, 22, 1783-1790. [CrossRef]

67. Otto, K.J.; Johnson, M.D.; Kipke, D.R. and Improve Unit Recordings With Chronically Implanted Microelectrodes. IEEE Trans. Biomed. Eng. 2006, 53, 333-340. [CrossRef]

68. Ludwig, K.A.; Uram, J.D.; Yang, J.; Martin, D.C.; Kipke, D.R. Chronic neural recordings using silicon microelectrode arrays electrochemically deposited with a poly(3,4-ethylenedioxythiophene) (PEDOT) film. J. Neural Eng. 2006, 3, 59-70. [CrossRef]

69. He, W.; McConnell, G.C.; Bellamkonda, R.V. Nanoscale laminin coating modulates cortical scarring response around implanted silicon microelectrode arrays. J. Neural Eng. 2006, 3, 316. [CrossRef]

70. Stice, P.; Gilletti, A.; Panitch, A.; Muthuswamy, J. Thin microelectrodes reduce GFAP expression in the implant site in rodent somatosensory cortex. J. Neural Eng. 2007, 4, 42-53. [CrossRef] [PubMed]

71. Musallam, S.; Bak, M.J.; Troyk, P.R.; Andersen, R.A. A floating metal microelectrode array for chronic implantation. J. Neurosci. Methods 2007, 160, 122-127. [CrossRef] [PubMed]

72. Rutherford, E.C.; Pomerleau, F.; Huettl, P.; Strömberg, I.; Gerhardt, G.A. Chronic second-by-second measures of L-glutamate in the central nervous system of freely moving rats. J. Neurochem. 2007, 102, 712-722. [CrossRef]

73. Williams, J.C.; Hippensteel, J.A.; Dilgen, J.; Shain, W.; Kipke, D.R. Complex impedance spectroscopy for monitoring tissue responses to inserted neural implants. J. Neural Eng. 2007, 4, 410-423. [CrossRef]

74. Hascup, E.R.; af Bjerkén, S.; Hascup, K.N.; Pomerleau, F.; Huettl, P.; Strömberg, I.; Gerhardt, G.A. Histological studies of the effects of chronic implantation of ceramic-based microelectrode arrays and microdialysis probes in rat prefrontal cortex. Brain Res. 2009, 1291, 12-20. [CrossRef] [PubMed]

75. McConnell, G.C.; Butera, R.J.; Bellamkonda, R.V. Bioimpedance modeling to monitor astrocytic response to chronically implanted electrodes. J. Neural Eng. 2009, 6, 055005. [CrossRef] [PubMed]

76. Venkatraman, S.; Hendricks, J.; Richardson-Burns, S.; Jan, E.; Martin, D.; Carmena, J.M. PEDOT coated microelectrode arrays for chronic neural recording and stimulation. In Proceedings of the 2009 4th International IEEE/EMBS Conference on Neural Engineering, Antalya, Turkey, 29 April-2 May 2009; Volume 4, pp. 383-386. [CrossRef] 
77. McConnell, G.C.; Rees, H.D.; Levey, A.I.; Gutekunst, C.A.; Gross, R.E.; Bellamkonda, R.V. Implanted neural electrodes cause chronic, local inflammation that is correlated with local neurodegeneration. J. Neural Eng. 2009, 6, 056003. [CrossRef] [PubMed]

78. Azemi, E.; Lagenaur, C.F.; Cui, X.T. The surface immobilization of the neural adhesion molecule L1 on neural probes and its effect on neuronal density and gliosis at the probe/tissue interface. Biomaterials 2011, 32, 681-692. [CrossRef] [PubMed]

79. Wang, J.; Wagner, F.; Diagne, M.; Borton, D.A.; Zhang, J.; Ozden, I.; Burwell, R.D.; Nurmikko, A.V.; van Wagenen, R.; Diester, I.; et al. Integrated device for combined optical neuromodulation and electrical recording for chronic in vivo applications. J. Neural Eng. 2012, 13, 016001. [CrossRef] [PubMed]

80. Venkatraman, S.; Hendricks, J.; King, Z.A.; Sereno, A.J.; Richardson-Burns, S.; Martin, D.; Carmena, J.M. In vitro and in vivo evaluation of PEDOT microelectrodes for neural stimulation and recording. IEEE Trans. Neural Syst. Rehabil. Eng. 2011, 19, 307-316. [CrossRef]

81. Prasad, A.; Sanchez, J.C. Quantifying long-term microelectrode array functionality using chronic in vivo impedance testing. J. Neural Eng. 2012, 9, 026028. [CrossRef]

82. Prasad, A.; Xue, Q.S.; Sankar, V.; Nishida, T.; Shaw, G.; Streit, W.J.; Sanchez, J.C. Comprehensive characterization and failure modes of tungsten microwire arrays in chronic neural implants. J. Neural Eng. 2012, 9, 056015. [CrossRef]

83. Kim, B.J.; Kuo, J.T.W.; Hara, S.A.; Lee, C.D.; Yu, L.; Gutierrez, C.A.; Hoang, T.Q.; Pikov, V.; Meng, E. 3D Parylene sheath neural probe for chronic recordings. J. Neural Eng. 2013, 10, 045002. [CrossRef] [PubMed]

84. Misra, A.; Kondaveeti, P.; Nissanov, J.; Barbee, K.; Shewokis, P.; Rioux, L.; Moxon, K.A. Preventing neuronal damage and inflammation in vivo during cortical microelectrode implantation through the use of Poloxamer P-188. J. Neural Eng. 2013, 10, 016011. [CrossRef] [PubMed]

85. Saxena, T.; Karumbaiah, L.; Gaupp, E.A.; Patkar, R.; Patil, K.; Betancur, M.; Stanley, G.B.; Bellamkonda, R.V. The impact of chronic blood-brain barrier breach on intracortical electrode function. Biomaterials 2013, 34, 4703-4713. [CrossRef] [PubMed]

86. Nguyen, J.K.; Park, D.J.; Skousen, J.L.; Hess-Dunning, A.E.; Tyler, D.J.; Rowan, S.J.; Weder, C.; Capadona, J.R. Mechanicallycompliant intracortical implants reduce the neuroinflammatory response. J. Neural Eng. 2014, 11, 056014. [CrossRef]

87. Mandal, H.S.; Knaack, G.L.; Charkhkar, H.; McHail, D.G.; Kastee, J.S.; Dumas, T.C.; Peixoto, N.; Rubinson, J.F.; Pancrazio, J.J. Improving the performance of poly(3,4-ethylenedioxythiophene) for brain-machine interface applications. Acta Biomater. 2014, 10, 2446-2454. [CrossRef]

88. Patel, P.R.; Na, K.; Zhang, H.; Kozai, T.D.Y.; Kotov, N.A.; Yoon, E.; Chestek, C.A. Insertion of linear $8.4 \mu \mathrm{m}$ diameter 16 channel carbon fiber electrode arrays for single unit recordings. J. Neural Eng. 2015, 12, 046009. [CrossRef]

89. Alba, N.A.; Du, Z.J.; Catt, K.A.; Kozai, T.D.Y.; Cui, X.T. In vivo electrochemical analysis of a PEDOT/MWCNT neural electrode coating. Biosensors 2015, 5, 618-646. [CrossRef]

90. Wu, F.; Tien, L.W.; Chen, F.; Berke, J.D.; Kaplan, D.L.; Yoon, E. Silk-backed structural optimization of high-density flexible intracortical neural probes. J. Microelectromechan. Syst. 2015, 24, 62-69. [CrossRef]

91. Charkhkar, H.; Knaack, G.L.; Mchail, D.G.; Mandal, H.S.; Peixoto, N.; Rubinson, J.F.; Dumas, T.C.; Pancrazio, J.J. Chronic intracortical neural recordings using microelectrode arrays coated with PEDOT-TFB. Acta Biomater. 2016, 32, 57-67. [CrossRef]

92. Patel, P.R.; Zhang, H.; Robbins, M.T.; Nofar, J.B.; Marshall, S.P.; Kobylarek, M.J.; Kozai, T.D.Y.; Kotov, N.A.; Chestek, C.A. Chronic in vivo stability assessment of carbon fiber microelectrode arrays. J. Neural Eng. 2016, 13, 066002. [CrossRef]

93. Hara, S.A.; Kim, B.J.; Kuo, J.T.W.; Lee, C.D.; Meng, E.; Pikov, V. Long-term stability of intracortical recordings using perforated and arrayed Parylene sheath electrodes. J. Neural Eng. 2016, 13, 066020. [CrossRef] [PubMed]

94. Yu, K.J.; Kuzum, D.; Hwang, S.W.; Kim, B.H.; Juul, H.; Kim, N.H.; Won, S.M.; Chiang, K.; Trumpis, M.; Richardson, A.G.; et al. Bioresorbable silicon electronics for transient spatiotemporal mapping of electrical activity from the cerebral cortex. Nat. Mater. 2016, 15, 782-791. [CrossRef] [PubMed]

95. Knaack, G.L.; McHail, D.G.; Borda, G.; Koo, B.; Peixoto, N.; Cogan, S.F.; Dumas, T.C.; Pancrazio, J.J. In vivo Characterization of Amorphous Silicon Carbide As a Biomaterial for Chronic Neural Interfaces. Front. Neurosci. 2016, 10, 301. [CrossRef] [PubMed]

96. Du, Z.J.; Kolarcik, C.L.; Kozai, T.D.Y.; Luebben, S.D.; Sapp, S.A.; Zheng, X.S.; Nabity, J.A.; Cui, X.T. Ultrasoft microwire neural electrodes improve chronic tissue integration. Acta Biomater. 2017, 53, 46-58. [CrossRef]

97. Goss-Varley, M.; Dona, K.R.; McMahon, J.A.; Shoffstall, A.J.; Ereifej, E.S.; Lindner, S.C.; Capadona, J.R. Microelectrode implantation in motor cortex causes fine motor deficit: Implications on potential considerations to Brain Computer Interfacing and Human Augmentation. Sci. Rep. 2017, 7, 15254. [CrossRef]

98. Black, B.J.; Kanneganti, A.; Joshi-Imre, A.; Rihani, R.; Chakraborty, B.; Abbott, J.; Pancrazio, J.J.; Cogan, S.F. Chronic recording and electrochemical performance of utah microelectrode arrays implanted in rat motor cortex. J. Neurophysiol. 2018, 120, 2083-2090. [CrossRef]

99. Cody, P.A.; Eles, J.R.; Lagenaur, C.F.; Kozai, T.D.Y.; Cui, X.T. Unique electrophysiological and impedance signatures between encapsulation types: An analysis of biological Utah array failure and benefit of a biomimetic coating in a rat model. Biomaterials 2018, 161, 117-128. [CrossRef]

100. Lo, M.C.; Wang, S.; Singh, S.; Damodaran, V.B.; Ahmed, I.; Coffey, K.; Barker, D.; Saste, K.; Kals, K.; Kaplan, H.M.; et al. Evaluating the in vivo glial response to miniaturized parylene cortical probes coated with an ultra-fast degrading polymer to aid insertion. J. Neural Eng. 2018, 15, 036002. [CrossRef] [PubMed]

101. Oakes, R.S.; Polei, M.D.; Skousen, J.L.; Tresco, P.A. An astrocyte derived extracellular matrix coating reduces astrogliosis surrounding chronically implanted microelectrode arrays in rat cortex. Biomaterials 2018, 154, 1-11. [CrossRef] 
102. Winter, B.M.; Daniels, S.R.; Salatino, J.W.; Purcell, E.K. Genetic modulation at the neural microelectrode interface: Methods and applications. Micromachines 2018, 9, 476. [CrossRef]

103. Joshi-Imre, A.; Black, B.J.; Abbott, J.; Kanneganti, A.; Rihani, R.; Chakraborty, B.; Danda, V.R.; Maeng, J.; Sharma, R.; Rieth, L.; et al. Chronic recording and electrochemical performance of amorphous silicon carbide-coated Utah electrode arrays implanted in rat motor cortex. J. Neural Eng. 2019, 16, 046006. [CrossRef]

104. Chuapoco, M.R.; Choy, M.; Schmid, F.; Duffy, B.A.; Lee, H.J.; Lee, J.H. Carbon monofilament electrodes for unit recording and functional MRI in same subjects. Neuroimage 2019, 186, 806-816. [CrossRef] [PubMed]

105. Cassar, I.R.; Yu, C.; Sambangi, J.; Lee, C.D.; Whalen, J.J.; Petrossians, A.; Grill, W.M. Electrodeposited platinum-iridium coating improves in vivo recording performance of chronically implanted microelectrode arrays. Biomaterials 2019, 205, 120-132. [CrossRef] [PubMed]

106. Stiller, A.M.; Usoro, J.O.; Lawson, J.; Araya, B.; González-González, M.A.; Danda, V.R.; Voit, W.E.; Black, B.J.; Pancrazio, J.J. Mechanically robust, softening shape memory polymer probes for intracortical recording. Micromachines 2020, 11, 619. [CrossRef] [PubMed]

107. Welle, E.J.; Patel, P.R.; Woods, J.E.; Petrossians, A.; Della Valle, E.; Vega-Medina, A.; Richie, J.M.; Cai, D.; Weiland, J.D.; Chestek, C.A. Ultra-small carbon fiber electrode recording site optimization and improved in vivo chronic recording yield. J. Neural Eng. 2020, 17, 026037. [CrossRef]

108. Guitchounts, G.; Cox, D. 64-Channel Carbon Fiber Electrode Arrays for Chronic Electrophysiology. Sci. Rep. 2020, 10, 3830. [CrossRef]

109. Xie, C.; Liu, J.; Fu, T.M.; Dai, X.; Zhou, W.; Lieber, C.M. Three-dimensional macroporous nanoelectronic networks as minimally invasive brain probes. Nat. Mater. 2015, 14, 1286-1292. [CrossRef]

110. Eldawlatly, S.; Oweiss, K.G. Temporal precision in population-But not individual neuron-Dynamics reveals rapid experiencedependent plasticity in the rat barrel cortex. Front. Comput. Neurosci. 2014, 8, 155. [CrossRef] [PubMed]

111. Jovalekic, A.; Cavé-Lopez, S.; Canopoli, A.; Ondracek, J.M.; Nager, A.; Vyssotski, A.L.; Hahnloser, R.H.R. A lightweight feedback-controlled microdrive for chronic neural recordings. J. Neural Eng. 2017, 14, 026006. [CrossRef]

112. Henry, K.S.; Neilans, E.G.; Abrams, K.S.; Idrobo, F.; Carney, L.H. Neural correlates of behavioral amplitude modulation sensitivity in the budgerigar midbrain. J. Neurophysiol. 2016, 115, 1905-1916. [CrossRef]

113. Maynard, E.M.; Fernandez, E.; Normann, R.A. A technique to prevent dural adhesions to chronically implanted microelectrode arrays. J. Neurosci. Methods 2000, 97, 93-101. [CrossRef]

114. McCreery, D.; Lossinsky, A.; Pikov, V.; Liu, X. Microelectrode array for chronic deep-brain microstimulation and recording. IEEE Trans. Biomed. Eng. 2006, 53, 726-737. [CrossRef] [PubMed]

115. Witte, R.S.; Rousche, P.J.; Kipke, D.R. Fast wave propagation in auditory cortex of an awake cat using a chronic microelectrode array. J. Neural Eng. 2007, 4, 68-78. [CrossRef] [PubMed]

116. Parker, R.A.; Davis, T.S.; House, P.A.; Normann, R.A.; Greger, B. The Functional Consequences of Chronic, Physiologically Effective Intracortical Microstimulation, 1st ed.; Elsevier: Amsterdam, The Netherlands, 2011; Volume 194, ISBN 9780444538154.

117. Kane, S.R.; Cogan, S.F.; Ehrlich, J.; Plante, T.D.; McCreery, D.B.; Troyk, P.R. Electrical performance of penetrating microelectrodes chronically implanted in cat cortex. IEEE Trans. Biomed. Eng. 2013, 60, 2153-2160. [CrossRef] [PubMed]

118. McCreery, D.; Cogan, S.; Kane, S.; Pikov, V. Correlations between histology and neuronal activity recorded by microelectrodes implanted chronically in the cerebral cortex. J. Neural Eng. 2016, 13, 036012. [CrossRef]

119. Carriero, G.; Arcieri, S.; Cattalini, A.; Corsi, L.; Gnatkovsky, V.; De Curtis, M. A guinea pig model of mesial temporal lobe epilepsy following nonconvulsive status epilepticus induced by unilateral intrahippocampal injection of kainic acid. Epilepsia 2012, 53, 1917-1927. [CrossRef]

120. Hoogerwerf, A.C.; Wise, K.D. A Three-Dimensional Microelectrode Array for Chronic Neural Recording. IEEE Trans. Biomed. Eng. 1994, 41, 1136-1146. [CrossRef]

121. Williams, J.C.; Rennaker, R.L.; Kipke, D.R. Long-term neural recording characteristics of wire microelectrode arrays implanted in cerebral cortex. Brain Res. Protoc. 1999, 4, 303-313. [CrossRef]

122. Weiland, J.D.; Anderson, D.J. Chronic neural stimulation with thin-film, iridium oxide electrodes. IEEE Trans. Biomed. Eng. 2000, 47, 911-918. [CrossRef]

123. Perkins, L.N.; Semu, D.; Shen, J.; Boas, D.A.; Gardner, T.J. High-density microfibers as a potential optical interface to reach deep brain region. J. Neural Eng. 2018, 15, 066002. [CrossRef]

124. Yin, M.; Borton, D.A.; Aceros, J.; Patterson, W.R.; Nurmikko, A. A 100-Channel Hermetically Sealed Implantable Device for Chronic Wireless Neurosensing Applications. IEEE Trans. Biomed. Circuits Syst. 2013, 7, 115-128. [CrossRef] [PubMed]

125. Sohal, H.S.; Jackson, A.; Jackson, R.; Clowry, G.J.; Vassilevski, K.; O’Neill, A.; Baker, S.N. The sinusoidal probe: A new approach to improve electrode longevity. Front. Neuroeng. 2014, 7, 10. [CrossRef] [PubMed]

126. Cogan, S.F.; Edell, D.J.; Guzelian, A.A.; Liu, Y.P.; Edell, R. Plasma-enhanced chemical vapor deposited silicon carbide as an implantable dielectric coating. J. Biomed. Mater. Res. Part A 2003, 67, 856-867. [CrossRef] [PubMed]

127. Swadlow, H.A.; Bereshpolova, Y.; Bezdudnaya, T.; Cano, M.; Stoelzel, C.R. A multi-channel, implantable microdrive system for use with sharp, ultra-fine "Reitboeck" microelectrodes. J. Neurophysiol. 2005, 93, 2959-2965. [CrossRef]

128. Sohal, H.S.; Clowry, G.J.; Jackson, A.; O’Neill, A.; Baker, S.N. Mechanical flexibility reduces the foreign body response to long-term implanted microelectrodes in rabbit cortex. PLOS ONE 2016, 11, e0165606. [CrossRef] 
129. Ghosh, S.; Putrino, D.; Burro, B.; Ring, A. Patterns of spatio-temporal correlations in the neural activity of the cat motor cortex during trained forelimb movements. Somatosens. Mot. Res. 2009, 26, 31-49. [CrossRef]

130. Schultz, R.L.; Willey, T.J. The ultrastructure of the sheath around chronically implanted electrodes in brain. J. Neurocytol. 1976, 5, 621-642. [CrossRef] [PubMed]

131. Agnew, W.F.; Yuen, T.G.H.; McCreery, D.B.; Bullara, L.A. Histopathologic evaluation of prolonged intracortical electrical stimulation. Exp. Neurol. 1986, 92, 162-185. [CrossRef]

132. Rousche, P.J.; Normann, R.A. Chronic recording capability of the utah intracortical electrode array in cat sensory cortex. J. Neurosci. Methods 1998, 82, 1-15. [CrossRef]

133. Normann, R.A.; Maynard, E.M.; Rousche, P.J.; Warren, D.J. A neural interface for a cortical vision prosthesis. Vision Res. 1999, 39, 2577-2587. [CrossRef]

134. Rousche, P.J.; Normann, R.A. Chronic intracortical microstimulation (ICMS) of cat sensory cortex using the utah intracortical electrode array. IEEE Trans. Rehabil. Eng. 1999, 7, 56-68. [CrossRef] [PubMed]

135. Liu, X.; McCreery, D.B.; Carter, R.R.; Bullara, L.A.; Yuen, T.G.H.; Agnew, W.F. Stability of the interface between neural tissue and chronically implanted intracortical microelectrodes. IEEE Trans. Rehabil. Eng. 1999, 7, 315-326. [CrossRef]

136. Lin, W.S.; Tillery, S.H.; He, J. Stability of the chronic multichannel recording neuron signals. Annu. Int. Conf. IEEE Eng. Med. Biol.-Proc. 2003, 3, 2193-2196. [CrossRef]

137. Suner, S.; Fellows, M.R.; Vargas-Irwin, C.; Nakata, G.K.; Donoghue, J.P. Reliability of signals from a chronically implanted, silicon-based electrode array in non-human primate primary motor cortex. IEEE Trans. Neural Syst. Rehabil. Eng. 2005, 13, 524-541. [CrossRef]

138. Griffith, R.W.; Humphrey, D.R. Long-term gliosis around chronically implanted platinum electrodes in the Rhesus macaque motor cortex. Neurosci. Lett. 2006, 406, 81-86. [CrossRef]

139. Santhanam, G.; Linderman, M.D.; Gilja, V.; Afshar, A.; Ryu, S.I.; Meng, T.H.; Shenoy, K.V. HermesB: A continuous neural recording system for freely behaving primates. IEEE Trans. Biomed. Eng. 2007, 54, 2037-2050. [CrossRef]

140. Eliades, S.J.; Wang, X. Chronic multi-electrode neural recording in free-roaming monkeys. J. Neurosci. Methods 2008, 172, 201-214. [CrossRef]

141. Dickey, A.S.; Suminski, A.; Amit, Y.; Hatsopoulos, N.G. Single-unit stability using chronically implanted multielectrode arrays. J. Neurophysiol. 2009, 102, 1331-1339. [CrossRef] [PubMed]

142. Fraser, G.W.; Schwartz, A.B. Recording from the same neurons chronically in motor cortex. J. Neurophysiol. 2012, 107, 1970-1978. [CrossRef]

143. Davis, T.S.; Parker, R.A.; House, P.A.; Bagley, E.; Wendelken, S.; Normann, R.A.; Greger, B. Spatial and temporal characteristics of V1 microstimulation during chronic implantation of a microelectrode array in a behaving macaque. J. Neural Eng. 2012, 9, 065003. [CrossRef] [PubMed]

144. Chen, K.H.; Dammann, J.F.; Boback, J.L.; Tenore, F.V.; Otto, K.J.; Gaunt, R.A.; Bensmaia, S.J. The effect of chronic intracortical microstimulation on the electrode-tissue interface. J. Neural Eng. 2014, 11, 026004. [CrossRef] [PubMed]

145. Jiang, J.; Willett, F.R.; Taylor, D.M. Relationship between microelectrode array impedance and chronic recording quality of single units and local field potentials. In Proceedings of the 2014 36th Annual International Conference of the IEEE Engineering in Medicine and Biology Society, Chicago, IL, USA, 26-30 August 2014; pp. 3045-3048. [CrossRef]

146. Jackson, A.; Fetz, E.E. Compact movable microwire array for long-term chronic unit recording in cerebral cortex of primates. J. Neurophysiol. 2007, 98, 3109-3118. [CrossRef]

147. Eleryan, A.; Vaidya, M.; Southerland, J.; Badreldin, I.S.; Balasubramanian, K.; Fagg, A.H.; Hatsopoulos, N.; Oweiss, K. Tracking single units in chronic, large scale, neural recordings for brain machine interface applications. Front. Neuroeng. 2014, 7, 23. [CrossRef]

148. Rajan, A.T.; Boback, J.L.; Dammann, J.F.; Tenore, F.V.; Wester, B.A.; Otto, K.J.; Gaunt, R.A.; Bensmaia, S.J. The effects of chronic intracortical microstimulation on neural tissue and fine motor behavior. J. Neural Eng. 2015, 12, 066018. [CrossRef]

149. Abe, H.; McManus, J.N.J.; Ramalingam, N.; Li, W.; Marik, S.A.; Borgloh, S.M. zum A.; Gilbert, C.D. Adult cortical plasticity studied with chronically implanted electrode arrays. J. Neurosci. 2015, 35, 2778-2790. [CrossRef]

150. Malaga, K.A.; Schroeder, K.E.; Patel, P.R.; Irwin, Z.T.; Thompson, D.E.; Nicole Bentley, J.; Lempka, S.F.; Chestek, C.A.; Patil, P.G. Data-driven model comparing the effects of glial scarring and interface interactions on chronic neural recordings in non-human primates. J. Neural Eng. 2015, 13, 016010. [CrossRef]

151. Richardson, A.G.; Weigand, P.K.; Sritharan, S.Y.; Lucas, T.H. A chronic neural interface to the macaque dorsal column nuclei. J. Neurophysiol. 2016, 115, 2255-2264. [CrossRef] [PubMed]

152. Barrese, J.C.; Aceros, J.; Donoghue, J.P. Scanning electron microscopy of chronically implanted intracortical microelectrode arrays in non-human primates. J. Neural Eng. 2016, 13, 026003. [CrossRef] [PubMed]

153. Sritharan, S.Y.; Richardson, A.G.; Weigand, P.K.; Planell-Mendez, I.; Liu, X.; Zhu, H.; Zhang, M.; Van der Spiegel, J.; Lucas, T.H. Somatosensory Encoding with Cuneate Nucleus Microstimulation: Detection of Artificial Stimuli. IEEE Eng. Med. Biol. 2016, 4719-4722. [CrossRef]

154. Suresh, A.K.; Winberry, J.E.; Versteeg, C.; Chowdhury, R.; Tomlinson, T.; Rosenow, J.M.; Miller, L.E.; Bensmaia, S.J. Methodological considerations for a chronic neural interface with the cuneate nucleus of macaques. J. Neurophysiol. 2017, 118, 3271-3281. [CrossRef] [PubMed] 
155. Kyle, C.T.; Permenter, M.R.; Vogt, J.A.; Rapp, P.R.; Barnes, C.A. Behavioral Impact of Long-Term Chronic Implantation of Neural Recording Devices in the Rhesus Macaque. Neuromodulation 2019, 22, 435-440. [CrossRef]

156. Debnath, S.; Prins, N.W.; Pohlmeyer, E.; Mylavarapu, R.; Geng, S.; Sanchez, J.C.; Prasad, A. Long-term stability of neural signals from microwire arrays implanted in common marmoset motor cortex and striatum. Biomed. Phys. Eng. Express 2018, 4, 055025. [CrossRef]

157. Hao, Y.; Riehle, A.; Brochier, T.G. Mapping horizontal spread of activity in monkey motor cortex using single pulse microstimulation. Front. Neural Circuits 2016, 10, 104. [CrossRef]

158. Budoff, S.A.; Yano, K.M.; De Mesquita, F.C.; Doerl, J.G.; De Santana, M.B.; Nascimento, M.S.L.; Kunicki, A.C.B.; De Araújo, M.F.P. Astrocytic response to acutely- and chronically-implanted microelectrode arrays in the marmoset (Callithrix jacchus) brain. Brain Sci. 2019, 9, 19. [CrossRef]

159. Barz, F.; Livi, A.; Lanzilotto, M.; Maranesi, M.; Bonini, L.; Paul, O.; Ruther, P. Versatile, modular 3D microelectrode arrays for neuronal ensemble recordings: From design to fabrication, assembly, and functional validation in non-human primates. J. Neural Eng. 2017, 14, 036010. [CrossRef] [PubMed]

160. Chauviere, L.; Pothof, F.; Gansel, K.S.; Klon-Lipok, J.; Aarts, A.A.A.; Holzhammer, T.; Paul, O.; Singer, W.J.; Ruther, P. In vivo recording quality of mechanically decoupled floating versus skull-fixed silicon-based neural probes. Front. Neurosci. 2019, 13, 464 . [CrossRef] [PubMed]

161. Schmidt, E.M.; Bak, M.J.; McIntosh, J.S. Long-term chronic recording from cortical neurons. Exp. Neurol. 1976, 52, 496-506. [CrossRef]

162. Loeb, G.E.; Bak, M.J.; Schmidt, E.M.; Salcman, M. Parylene as a Chronically Stable, Reproducible Microelectrode Insulator. IEEE Trans. Biomed. Eng. 1977, BME-24, 121-128. [CrossRef] [PubMed]

163. Schmidt, E.M.; Mcintosh, J.S.; Bak, M.J. Long-term implants of Parylene-C coated microelectrodes. Med. Biol. Eng. Comput. 1988, 26, 96-101. [CrossRef] [PubMed]

164. Nicolelis, M.A.L.; Dimitrov, D.; Carmena, J.M.; Crist, R.; Lehew, G.; Kralik, J.D.; Wise, S.P. Chronic, multisite, multielectrode recordings in macaque monkeys. Proc. Natl. Acad. Sci. USA 2003, 100, 11041-11046. [CrossRef]

165. Zhang, C.Y.; Aflalo, T.; Revechkis, B.; Rosario, E.R.; Ouellette, D.; Pouratian, N.; Andersen, R.A. Partially Mixed Selectivity in Human Posterior Parietal Association Cortex. Neuron 2017, 95, 697-708. [CrossRef] [PubMed]

166. Zhang, C.Y.; Aflalo, T.; Revechkis, B.; Rosario, E.; Ouellette, D.; Pouratian, N.; Andersen, R.A. Preservation of partially mixed selectivity in human posterior parietal cortex across changes in task context. eNeuro 2020, 7, 1-16. [CrossRef] [PubMed]

167. Ramos-Murguialday, A.; Curado, M.R.; Broetz, D.; Yilmaz, Ö.; Brasil, F.L.; Liberati, G.; Garcia-Cossio, E.; Cho, W.; Caria, A.; Cohen, L.G.; et al. Brain-Machine Interface in Chronic Stroke: Randomized Trial Long-Term Follow-up. Neurorehabil. Neural Repair 2019, 33, 188-198. [CrossRef] [PubMed]

168. Hochberg, L.R.; Serruya, M.D.; Friehs, G.M.; Mukand, J.A.; Saleh, M.; Caplan, A.H.; Branner, A.; Chen, D.; Penn, R.D.; Donoghue, J.P. Neuronal ensemble control of prosthetic devices by a human with tetraplegia. Nature 2006, 442, 164-171. [CrossRef]

169. Simeral, J.D.; Kim, S.P.; Black, M.J.; Donoghue, J.P.; Hochberg, L.R. Neural control of cursor trajectory and click by a human with tetraplegia 1000 days after implant of an intracortical microelectrode array. J. Neural Eng. 2011, 8, 025027. [CrossRef]

170. Klaes, C.; Kellis, S.; Aflalo, T.; Lee, B.; Pejsa, K.; Shanfield, K.; Hayes-Jackson, S.; Aisen, M.; Heck, C.; Liu, C.; et al. Hand shape representations in the human posterior parietal cortex. J. Neurosci. 2015, 35, 15466-15476. [CrossRef]

171. Aflalo, T.; Kellis, S.; Klaes, C.; Lee, B.; Shi, Y.; Pejsa, K.; Shanfield, K.; Hayes-Jackson, S.; Aisen, M.; Heck, C.; et al. Decoding motor imagery from the posterior parietal cortex of a tetraplegic human. Science 2015, 348, 906-910. [CrossRef]

172. Downey, J.E.; Weiss, J.M.; Muelling, K.; Venkatraman, A.; Valois, J.S.; Hebert, M.; Bagnell, J.A.; Schwartz, A.B.; Collinger, J.L. Blending of brain-machine interface and vision-guided autonomous robotics improves neuroprosthetic arm performance during grasping. J. Neuroeng. Rehabil. 2016, 13, 28. [CrossRef]

173. Flesher, S.N.; Collinger, J.L.; Foldes, S.T.; Weiss, J.M.; Downey, J.E.; Tyler-Kabara, E.C.; Bensmaia, S.J.; Schwartz, A.B.; Boninger, M.L.; Gaunt, R.A. Intracortical microstimulation of human somatosensory cortex. Sci. Transl. Med. 2016, 8, 1-10. [CrossRef]

174. Kozai, T.D.Y.; Li, X.; Bodily, L.M.; Caparosa, E.M.; Zenonos, G.A.; Carlisle, D.L.; Friedlander, R.M.; Cui, X.T. Effects of caspase-1 knockout on chronic neural recording quality and longevity: Insight into cellular and molecular mechanisms of the reactive tissue response. Biomaterials 2014, 35, 9620-9634. [CrossRef] [PubMed]

175. Bedell, H.; Capadona, J. Anti-inflammatory Approaches to Mitigate the Neuroinflammatory Response to Brain-Dwelling Intracortical Microelectrodes. J. Immunol. 2018, 2, 15. [CrossRef]

176. Bedell, H.W.; Hermann, J.K.; Ravikumar, M.; Lin, S.; Rein, A.; Li, X.; Molinich, E.; Smith, P.D.; Selkirk, S.M.; Miller, R.H.; et al. Targeting CD14 on blood derived cells improves intracortical microelectrode performance. Biomaterials 2018, 163, 163-173. [CrossRef]

177. Kilborn, S.H.; Trudel, G.; Uhthoff, H. Review of Growth Plate Closure Compared with Age at Sexual Maturity and Lifespan in Laboratory Animals. Contemp. Top. Lab. Anim. Sci. 2002, 41, 21-26. [PubMed]

178. Kozai, T. The History and Horizons of Microscale Neural Interfaces. Micromachines 2018, 9, 445. [CrossRef]

179. Prasad, A.; Xue, Q.; Dieme, R.; Sankar, V.; Mayrand, R.C.; Nishida, T.; Streit, W.J.; Sanchez, J.C. Abiotic-biotic characterization of $\mathrm{Pt} / \mathrm{Ir}$ microelectrode arrays in chronic implants. Front. Neuroeng. 2014, 7, 2. [CrossRef] [PubMed]

180. Anderson, J.M. Biological responses to materials. Annu. Rev. Mater. Sci. 2001, 31, 81-110. [CrossRef] 
181. Banks, W.A.; Erickson, M.A. The blood-brain barrier and immune function and dysfunction. Neurobiol. Dis. 2010, 37, 26-32. [CrossRef] [PubMed]

182. Bennett, C.; Samikkannu, M.; Mohammed, F.; Dietrich, W.D.; Rajguru, S.M.; Prasad, A. Blood brain barrier (BBB)-disruption in intracortical silicon microelectrode implants. Biomaterials 2018, 164, 1-10. [CrossRef] [PubMed]

183. Ravikumar, M.; Sunil, S.; Black, J.; Barkauskas, D.S.; Haung, A.Y.; Miller, R.H.; Selkirk, S.M.; Capadona, J.R. The roles of blood-derived macrophages and resident microglia in the neuroinflammatory response to implanted Intracortical microelectrodes. Biomaterials 2014, 35, 8049-8064. [CrossRef] [PubMed]

184. Tresco, P.A.; Winslow, B.D. The challenge of integrating devices into the central nervous system. Crit. Rev. Biomed. Eng. 2011, 39, 29-44. [CrossRef]

185. Gilletti, A.; Muthuswamy, J. Brain micromotion around implants in the rodent somatosensory cortex. J. Neural Eng. 2006, 3, 189-195. [CrossRef]

186. Subbaroyan, J.; Martin, D.C.; Kipke, D.R. A finite-element model of the mechanical effects of implantable microelectrodes in the cerebral cortex. J. Neural Eng. 2005, 2, 103-113. [CrossRef]

187. Lee, H.; Bellamkonda, R.V.; Sun, W.; Levenston, M.E. Biomechanical analysis of silicon microelectrode-induced strain in the brain. J. Neural Eng. 2005, 2, 81-89. [CrossRef]

188. Prodanov, D.; Delbeke, J. Mechanical and Biological Interactions of Implants with the Brain and Their Impact on Implant Design. Front. Neurosci. 2016, 10, 11. [CrossRef] [PubMed]

189. Potter, K.A.; Buck, A.C.; Self, W.K.; Capadona, J.R. Stab injury and device implantation within the brain results in inversely multiphasic neuroinflammatory and neurodegenerative responses. J. Neural Eng. 2012, 9, 046020. [CrossRef] [PubMed]

190. Xie, Y.; Martini, N.; Hassler, C.; Kirch, R.D.; Stieglitz, T.; Seifert, A.; Hofmann, U.G. In vivo monitoring of glial scar proliferation on chronically implanted neural electrodes by fiber optical coherence tomography. Front. Neuroeng. 2014, 7, 34. [CrossRef] [PubMed]

191. Shoffstall, A.; Capadona, J.R. Prospects for a Robust Cortical Recording Interface, 2nd ed.; Elsevier Ltd.: Amsterdam, The Netherlands, 2018; ISBN 9780128053539. 